\title{
The Modelling of Groundwater Table Management for Canal Blocking Scenarios In Sub Peatland Hydrological Unit
}

\author{
Ivan Aliyatul Humam ${ }^{*}$, Abdul Chalid ${ }^{2}$, Bagus Prasetyo ${ }^{3}$ \\ ${ }^{1}$ Graduate from Master of Water Resources Management, \\ Faculty of Civil and Environmental Engineering, Bandung Institute of Technology \\ ${ }^{2}$ Lecturer of Civil Engineering Postgraduate, Faculty of Engineering \\ Sangga Buana YKPP University \\ ${ }^{3}$ Graduate from Master of Water Resources Engineering, \\ Faculty of Civil and Environtmental Engineering, Bandung Institute of Technology \\ ${ }^{*}$ Corresponding author: \\ Email: ivanmpsda@gmail.com
}

\begin{abstract}
.
Drainage in peatland caused reducing water storage and subsidence. Groundwater level fluctuations are a major role in the water balance that occurs in peatlands. The research was conducted in a specific area of agricultural peatland. The location in Sub-Peatland Hydrological Unit (Sub-PHU) 5 and 6 Kahayan Sebangau, Central Kalimantan Province, Indonesia. Modeling for groundwater table was applied using Freewat / Modflow software with input rainfall probability 80\% (R80), infiltration, and evapotranspiration data analysis. Groundwater table should not be less than minus 0.4 meters based on the Indonesian Ministry of Environment and Forestry (Menlhk). The deficit means the groundwater level below $-0.4 \mathrm{~m}$ and surplus upon the criteria. Land modeling is simulated with an area of $300 \times 1000$ meters. The calibration in the model was found conductivity values, $50 \mathrm{~m} /$ day or $5.78 \times 10-4 \mathrm{~m} /$ $s$ with the best value with the largest NSE and Correlation. The modeling showed that the deficit occurred in seven months. The groundwater management is how to keep the water level upon $-0.4 \mathrm{~m}$ with the planning of canal blocking height. The scenarios are $0.2 \mathrm{~m} .0 .3 \mathrm{~m}, 0.4 \mathrm{~m}$, and $0.5 \mathrm{~m}$ upon the base flow of the canal. The best scenario was chosen $0.5 \mathrm{~m}$ according to the simulation which has the water level upon $-0.4 \mathrm{~m}$.
\end{abstract}

Keywords: Modeling, Groundwater, Canal Blocking,Peatland, Restoration.

\section{INTRODUCTION}

Peatland is a land composed of imperfect decomposition of vegetation from waterlogged trees so that the condition is anaerobic. The organic material continues to accumulate for a long time so that it forms layers with a thickness of more than $50 \mathrm{~cm}$. Peat is generally defined as the accumulation of plant remains found under stagnant, acidic conditions, and being in the soil, which causes incomplete decomposition [1]. Tropical peatlands have important functions in the hydrological cycle, carbon, and climate change. Peatland management is very important not just in the national area but 
it has become an international issue. Osaki [2] explain that the existence of tropical peatlands has an important function in the water cycle, carbon, and climate change. In addition to the release of increased carbon emissions in drained peatland[3], other hazards, and disaster from the destruction of tropical peat ecosystems are occurring subsidence [4], fire-prone [5], floods [6], and climate change [7]. In the case of tropical peatlands, drastic groundwater levels occur. This needs to be anticipated for fire disasters. Besides, sustainable management can improve the standard of living of people in agriculture.

The fires on peatlands were caused by the construction of canals to make the water level drop. On the other hand, changes in land use from forests to oil palm plantations have an impact on groundwater levels, as explained Pasaribu[8] researching the hydrological cycle and water requirements on peatlands that have been converted into oil palm plantations in Riau, while Kumagai [9] examines the hydrology of oil palm plantations in Sarawak both oil palm plantations experienced a reduction in groundwater storage. Groundwater level fluctuations affect the water balance that occurs in peatlands [10]. Predictions of groundwater level fluctuations are important for effective resource management[11]. Modeling using Modflow and Simgro was developed to measure groundwater by assessing water balance in peatlands [12]. The water balance was also investigated by forested ombrotrophic peatlands and shortrange burnt peatlands resulting in higher evapotranspiration output occurring in burning peatlands[13]. The peatland management should be restored the natural forest and created economic incentive for local community[14].

In peatlands the type of aquifer is unconfined or aquifer is not repressed. Modeling for 20 years is expected to produce water level fluctuation graphs. Behavior in the rainy season and dry season have their respective characteristics. Fluctuations that occur can be used for data in infrastructure planning to manage water resources in peatlands. Central Kalimantan Province is an area that has degraded peatlands. Canals that have been built are major causes of serious environmental damage due to the draining of peat and fires happening regularly.

Water management must meet the optimal water requirements for crops and peat restoration[15]. In general, there are several principles of restoration, namely wetting peatlands and maintaining moisture[16]. It is necessary to understand more that peatlands, vegetation and water are interconnected and need each other [17]. On cultivated peat, the land must be moist with an optimal water level for restoration. When the water level lower than before, there will be oxidation and then the peat will decompose[18]. More severe fires can also occur. Fires usually stop when it rains and the groundwater level rises again. The water level is kept not lower than $-40 \mathrm{~cm}$ to prevent fires [19]. In the water management system on peatlands, canals that drain water reservoirs must be constructed with blocking canals[20].

Regarding the protection of peatlands in Indonesia, the issuance of the new regulation by KLHK is an effort to implement Government Regulation 71/2014 concerning Protection and Management of Peat Ecosystems, Law 32/2009 concerning Environmental Protection and Management and the 1945 Constitution. All of these laws prohibit land clearing in protected peat areas and require business owners to mitigate and restore peat damaged by business activities. With the problems mentioned it needs to do modeling of the groundwater level that occurs in the study area. 
Groundwater fluctuations occurring is found to plan the water infrastructure. The modeling is used for agricultural planning by considering the balance of the peatland ecosystem.

\section{METHODS}

\subsection{Study Location}

The scope of the study area is limited to hydrological sub-units 5 and 6 (sub-KHG 5 and 6) which are peat hydrological areas in the upstream part of Palangkaraya City and a small part of Pulang Pisau district, Central Kalimantan. Palangkaraya City Region is located in the equator, which is between $0^{\circ}$ to $10^{\circ}$ South Latitude and $110^{\circ}$ to $120^{\circ}$ East Longitude. Central Kalimantan Province has waters that include lakes, marshes, and is crossed by river routes namely the Kahayan river and the Sebangau river.

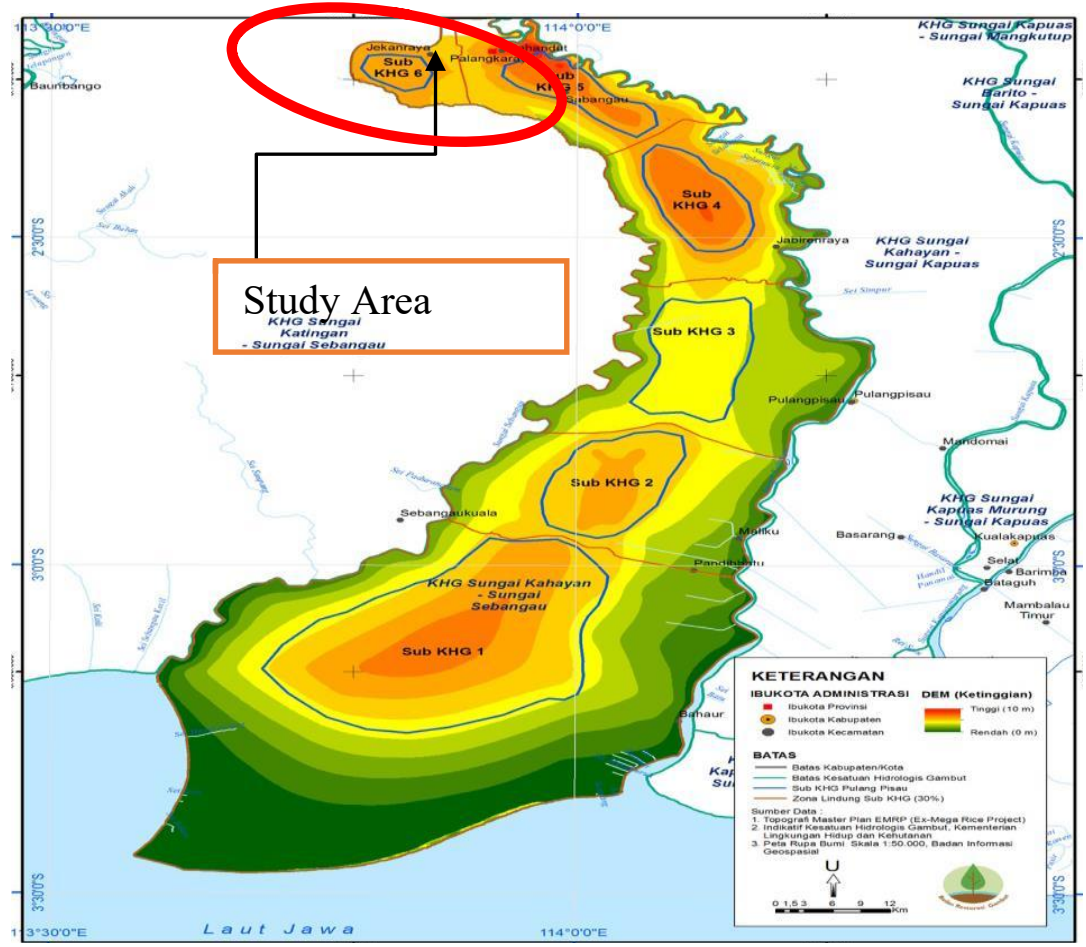

Figure 1. Study Area (Dohong et all,. 2016)

\subsection{Modeling with Freewat/Modflow}

FREEWAT is understood as a joint plugin for the famous GIS open-source desktop software, QGIS. The reference version chosen from QGIS is the latest LTR (Long Term Release), which is QGIS 2.14. As a combined plugin, FREEWAT is designed as a modular ensemble of different tools: some of them can be used independently, while some modules require initial execution from other tools. This modeling framework is based on differences in MODFLOW groundwater flow and related codes that are known throughout the world [23], by integrating primarily the MODFLOW-2005 version. MODFLOW aims to simulate the dynamics of 
groundwater flow in saturated and unsaturated zones, both in limited aquifers and without bonds with thickness and transmissivity values constant or in variables, under steady or transient conditions. The numerical settlement method uses the equation of the groundwater flow equation. The formula is as follows :

$$
\frac{\partial}{\partial x}\left(T_{X} \frac{\partial H}{\partial x}\right)+\frac{\partial}{\partial y}\left(T_{y} \frac{\partial H}{\partial y}\right) \pm Q(x, y, t)=S_{S} \frac{\partial H}{\partial t}
$$

$\mathrm{H}=$ High water level until the surface is free [L]

$\mathrm{Tx}, \mathrm{Tx}=$ pseudo transmissivity $[\mathrm{L} / \mathrm{T}]$

Ss $\quad=$ Storage coefficient $(1 / \mathrm{L}]$.

Q $\quad=$ Discharge per unit volume of aquifer added (injection / positive) or subtracted (pumping/negative) from the groundwater system.

\subsection{Collecting Data}

Data collection methods by collecting data from relevant agencies and collection of journals or other literature relating to the title. This study uses secondary data from several agencies. The data used include the following :

Table 1. Collecting Data Tables

\begin{tabular}{lll}
\hline Data & Sources Data & Decision \\
\hline Topografi Data (DEM) & USGS,DEMNAS & $\begin{array}{l}\text { Input Modflow dan } \\
\text { Initial Boundaries } \\
\text { Calculate }\end{array}$ \\
Rainfall Data & $\begin{array}{l}\text { Research and } \\
\text { Development Center }\end{array}$ & $\begin{array}{l}\text { Presipitation } \\
\text { for Water Resources }\end{array}$ \\
Climatology Data & EUSAIR) & Evapotranspiration \\
$\begin{array}{l}\text { Observation of water } \\
\text { level data }\end{array}$ & Peat Restoration & Initial Heads/Input \\
Geometry aquifer data & Agency (BRG) & Input Modflow \\
General Data & Journals & Location data \\
\hline
\end{tabular}

\subsection{Collecting Data}

The concept of water management at PHU 5 and 6 Kahayan Sebangau Central Kalimantan Province is to make blocking canals in drainage channels so that the groundwater level remains in a stable condition. The water level in the land is strongly influenced by the canal water level, rain, and evapotranspiration. Meanwhile, the water level of the canal is influenced by the boundary canal. The initial method is to calculate a probability of $80 \%$ of the rainfall data for 20 years. Climatological data were used to calculate evapotranspiration. Modeling was simulated by Freewat software and calibrated with field data. The models that are suitable in the field were simulated with various canal blocking scenarios. The output of this research will determine the best scenario for groundwater management following regulations. 


\section{RESULT AND DISCUSSION}

\subsection{Calibration of Conductivity Value}

The canal used as a calibration model has a length of about $8 \mathrm{~km}$. From the length of $8 \mathrm{~km}, 3.5 \mathrm{~km}$ is the community area and $4.5 \mathrm{~km}$ upstream is the Village Forest area. The canal has a width of about $10 \mathrm{~m}$. Peat depth varies around 4-8 $\mathrm{m}$. the calibration uses data 30 days with 8 observation points within 50 meters. The length of the canal for the calibration is used 950 meters. Canal Blocking is carried out upstream and downstream (Figure IV.1). The monitoring wellpoint has a name to make easy the modeling.

The modeling on top is numerical compared with the groundwater level in the field. Simulations are done by incorporating rain and evapotranspiration of plants that occurred in the field for calibration models. The first calibration graph used monitoring wells 6 and monitoring wells 8 for modeling monitoring wells 7 . The well 8 was made the initial boundary for modeling. After trying several conductivity values used $50 \mathrm{~m} /$ day or $5.78 \times 10-4 \mathrm{~m} / \mathrm{s}$ is the best value with the largest NSE and Correlation.

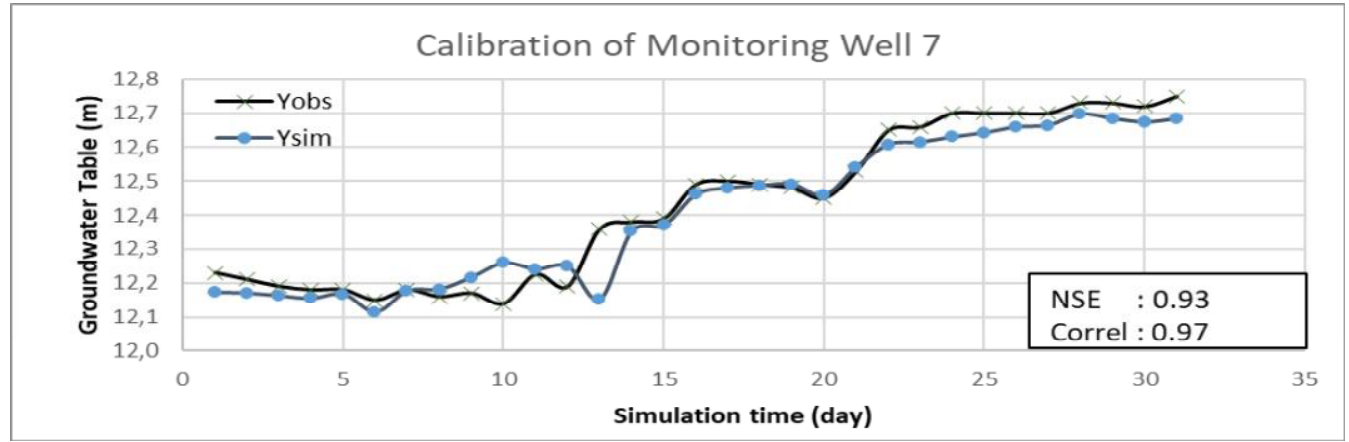

Figure 2. Calibration Value with Groundwater Table from Local Level [10]

\subsection{Analysis Water Table Fluctuation on Canal}

Land level data obtained from the Peat Restoration Agency (BRG) data. The data is used to determine the water level in the canal. The modeling process includes the input of rainfall, evapotranspiration, conductivity values, and water level in the land. After the process is carried out, the water level in the canal is obtained. While the modeling channel map is shown in the figure below. Modeling Using the Freewat / Modflow Application with Limits according to the data and environment in which the modeling is based. Input Conductivity values are $50 \mathrm{~m} /$ day or $1.78 \times 104 \mathrm{~m} / \mathrm{s}$ based on the calibration in chapter IV. Peat thickness 4-5 meters according to map thickness of peat. From the explanation above is made a graph of the relationship between rain minus evapotranspiration with the increase in water level in the land and then simulated per day for 1 year. The results are obtained as below. 


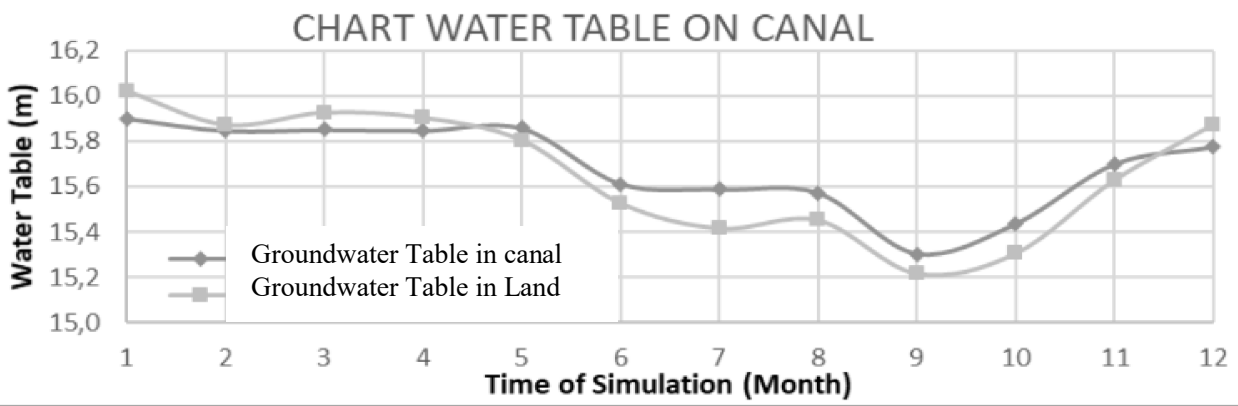

Figure 3. Water Table Fluctuation on the canal from the Local Level [10]

\subsection{Calculate of Evapotranspiration}

Climatology data is obtained online at the BMKG website. Evapotranspiration calculations based on climate data for nine years from 2000 to 2016 are secondary data from the Tjilik Riwut Meteorological Station in the area closest to the Research, for the calculation of ETo reference evapotranspiration using the Penman Modification method.

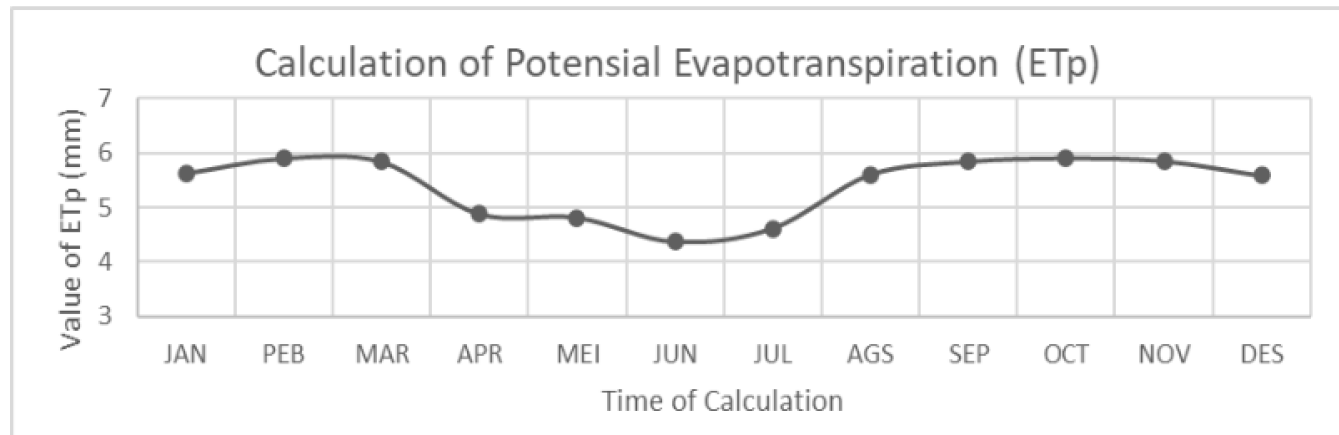

Figure 4. Evapotranspiration Value [10]

\subsection{Modeling Groundwater Table Fluctuation}

Modeling Using the Freewat / Modflow Application with Limits according to the data and environment in which the modeling is based. Input Conductivity values are $50 \mathrm{~m} /$ day or $1.78 \times 104 \mathrm{~m} / \mathrm{s}$ based on the calibration in chapter IV. Peat thickness 4-5 meters according to the peat thickness map. A graph is made of the relationship between rain minus evapotranspiration and rising water levels in the land and then simulating for a year the availability of rain and evapotranspiration data. The results are obtained from the graph below. 


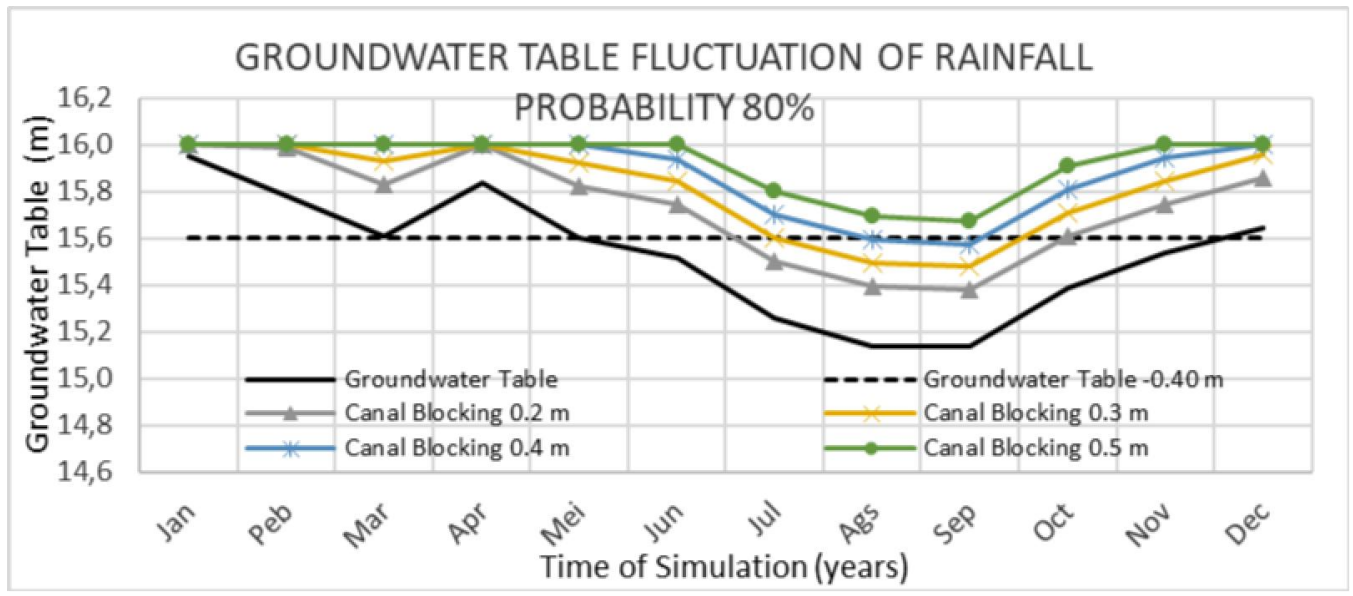

Figure 5. Groundwater Table Fluctuation

Based on calculations, there were 7 months of Failure incidents out of a total of 12 months or reliability of around $41.7 \%$. It is necessary to choose the height of the canal bocking and groundwater table so that the reliability is higher. With all scenario optimization, the canal blocking 0.5 meters is the best scenario can be applied.

Table 3. Reliability Canal Blocking

\begin{tabular}{cccccc}
\hline & \multicolumn{5}{c}{ Reability of Canal Blocking } \\
\cline { 2 - 5 } $\begin{array}{c}\text { Canal } \\
\text { Blocking }\end{array}$ & Failure (Month) & Reliability & $\begin{array}{c}\text { Water } \\
\text { Table } \\
\text { Extrem } \\
(\mathrm{m})\end{array}$ & $\begin{array}{c}\text { Minimal } \\
\text { Water Table } \\
(\mathrm{m})\end{array}$ & Decision \\
\cline { 2 - 5 } Without & 7 & $41.7 \%$ & -0.86 & -0.4 & No \\
Blocking & 3 & $75.0 \%$ & -0.62 & -0.4 & No \\
0.2 & 2 & $83.3 \%$ & -0.52 & -0.4 & No \\
0.3 & 2 & $83.3 \%$ & -0.42 & -0.4 & No \\
0.4 & 0 & $100.0 \%$ & -0.32 & -0.4 & Ok \\
0.5 & & & & & \\
\hline
\end{tabular}

\section{CONCLUSION}

Peat management issues required serious planning. The peatland is sensitive ecosystem which usefull to restore. Groundwater level management is the focus in this research. The conclusions of this study explained below:

1. Modeling was analysed by including input rainfall, infiltration and evapotranspiration.

2. Calibration was calculated using field data to find the value of hydraulic conductivity, get the optimal number of $50 \mathrm{~m} /$ day or $5.79 \times 10-3 \mathrm{~m} / \mathrm{s}$, it shows an NSE is more than 0.8 and a correlation value is more than 0.9 . 
3. The 20 years of availability data rainfall is analyzed to be 80 percent probability for agriculture purposes in peat. There was a deficit for 7 months because the ground water level was below the specified requirements. We did a simulation by building a blocking canal with various scenarios. the construction of the canal bocking able to increase the groundwater table and reduce the months of deficit. The 0.2 canal bocking causes 3 months of deficit, 0.3 canal bocking causes 2 months of deficit, the 0.4-meter canal bocking causes 2 months of deficit and the 0.5 -meter canal bocking is the best scenario with no deficit months.

4. This research is useful for determining optimal canal planning in certain cases on peatlands.

\section{ACKNOWLEDGMENTS}

The author would like to say thank to the PUSLITBANG in Bandung, which has helped in hydrological data for the research analysis process.

\section{REFERENCES}

[1] H. Rydin and J. K. Jeglum, The Biology of Peatlands (The Biology of Habitat). Oxford University Press, 2006.

[2] M. Osaki and N. Tsuji, Eds., Tropical Peatland Ecosystems. Tokyo: Springer Japan, 2016.

[3] L. S. Wijedasa, S. Sloan, S. E. Page, G. R. Clements, M. Lupascu, and T. A. Evans, "Carbon emissions from South-East Asian peatlands will increase despite emissionreduction schemes," Glob. Change Biol., vol. 24, no. 10, pp. 4598-4613, Oct. 2018, doi: 10.1111/gcb.14340.

[4] A. Hooijer et al., "Subsidence and carbon loss in drained tropical peatlands," Biogeosciences, vol. 9, no. 3, pp. 1053-1071, Mar. 2012, doi: 10.5194/bg-9-1053-2012.

[5] H. Wosten, A. Hooijer, C. Siderius, D. S. Rais, A. Idris, and J. Rieley, "Tropical Peatland water management modelling of the Air Hitam Laut catchment in Indonesia," Int. J. River Basin Manag., vol. 4, no. 4, pp. 233-244, Dec. 2006, doi: 10.1080/15715124.2006.9635293.

[6] E. Sumarga, L. Hein, A. Hooijer, and R. Vernimmen, "Hydrological and economic effects of oil palm cultivation in Indonesian peatlands," Ecol. Soc., vol. 21, no. 2, pp. 119, 2016, doi: 10.5751/ES-08490-210252.

[7] R. Biancalani, A. Avagyan, and Food and Agriculture Organization of the United Nations, Eds., Towards climate-responsible peatlands management. Rome: Food and Agriculture Organization of the United Nations (FAO), 2014.

[8] H. Pasaribu, A. Mulyadi, and S. Tarumun, "Water Balance in Palm Oil Plantation in PKKS Sub Unit Kalianta Kabun Riau,” J. Environ. Sci., pp. 99-113, 2012.

[9] T. Kumagai et al., "Annual water balance and seasonality of evapotranspiration in a Bornean tropical rainforest," Agric. For. Meteorol., vol. 128, no. 1-2, pp. 81-92, Jan. 2005, doi: 10.1016/j.agrformet.2004.08.006.

[10] I. A. Humam, "Modelling of Water Balance and Groundwater Table in Peatland Hydrological Unit 5 and 6 Kahayan Sebangau, Central Kalimantan Province," in Master Thesis, Bandung Institute of Technology, 2019, pp. 1-98. 
[11] M. Sadat-Noori, W. Glamore, and D. Khojasteh, "Groundwater Level Prediction Using Genetic Programming: the Importance of Precipitation Data and Weather Stasion Location on Model Accuracy," Environ. Earth Sci., pp. 1-10, 2020.

[12] H. Ritzema and H. Jansen, "Assesing The Water Balance of Tropical Peatlands by Inverse Groundwater Modelling," 13th Int. Peat Congr. "After Wise Use - Future Peatl., pp. 1-18, 2008.

[13] D. K. Thompson, B. W. Benscoter, and J. M. Waddington, "Water balance of a burned and unburned forested boreal peatland: Water Balance Of Boreal Peatlands Subject To Wildfire," Hydrol. Process., vol. 28, no. 24, pp. 5954-5964, Nov. 2014, doi: 10.1002/hyp.10074.

[14] H. Gunawan, S. Kobayashi, K. Mizuno, Y. Kono, and O. Kozan, "Sustainable Management Model for Peatland Ecosystems in the Riau, Sumatra," in Tropical Peatland Ecosystems, M. Osaki and N. Tsuji, Eds. Tokyo: Springer Japan, 2016, pp. 113-123.

[15] J. H. M. Wosten and H. P. Ritzema, "Land and Water Management Option for Peatland Development in Sarawak,Malaysia.” International Peat Journal, 1997.

[16] H. Joosten, M.-L. Tapio-Biström, Wetlands International, and S. tol, Eds., Peatlands: guidance for climate change mitigation through conservation, rehabilitation and sustainable use, 2nd ed. Rome: Food and Agriculture Organization of the United Nations : Wetlands International, 2012.

[17] S. E. Page, J. O. Rieley, Ò. W. Shotyk, and D. Weiss, "Interdependence of peat and vegetation in a tropical peat swamp forest," p. 14, 1999.

[18] R. Dommain, J. Couwenberg, and H. Joosten, "Hydrological self-regulation of domed peatlands in south-east Asia and consequences for conservation and restoration," p. 17, 2010.

[19] E. I. Putra, "The effect of the precipitation pattern of the dry season on peat fire occurrence in the Mega Rice Project area, Central Kalimantan, Indonesia," Tropics, vol. 19, no. 4, pp. 145-156, 2011, doi: 10.3759/tropics.19.145.

[20] H. Ritzema, S. Limin, K. Kusin, J. Jauhiainen, and H. Wösten, "Canal blocking strategies for hydrological restoration of degraded tropical peatlands in Central Kalimantan, Indonesia," CATENA, vol. 114, pp. 11-20, Mar. 2014, doi: 10.1016/j.catena.2013.10.009.

[21] S. Moghadas, "Long-term Water Balance of an Inland River Basin in an Arid Area, North-Western China," Master Sci. Thesis Water Resour. Div. Water Resour. Lund Inst. Technol. Lund Univ., p. 75, 2009.

[22] C. W. Thornthwaite and J. R. Mather, "Instructions and tables for computing potential evapotranspiration and the water balance." Publ. Climatol., 1957.

[23] M. G. McDonald and A. W. Harbaugh, "A Modular Three Dimensional Finite-Difference Ground-Water Flow Model,” pp. 1-539, 1984. 